\title{
Impact of Oil Price Changes on Certain Budget Variables, Government and Tax Revenues, External Grants, and Government Expenditures in Jordan
}

\author{
Amjad Qwader $^{1}$ \\ ${ }^{1}$ College of Business, Tafila Technical University, Jordan \\ Correspondence: Amjad Qwader, Tafila Technical University, College of Business, AT-Tafila, P.O. Box 179, \\ Tafila, 66110, Jordan. E-mail: amjad.qwader73@gmail.com
}

Received: May 13, 2018

Accepted: May 26, 2018

Online Published: June 15, 2018

doi:10.5539/ijef.v10n7p150

URL: https://doi.org/10.5539/ijef.v10n7p150

\begin{abstract}
This study evaluated the impact of oil price changes on certain budget variables in Jordan over the period of 1992 to 2015. Time series data were analyzed using econometric techniques that included ordinary least squares. Findings from the analysis revealed a statistically significant positive correlation for oil price on government and tax revenues, external grants, and government expenditures, whereas oil price on budget deficits had a statistically significant negative correlation. Therefore, the study proposes that the government of Jordan directly invests its oil tax revenues in economic sectors, such as agriculture and manufacturing, to broaden the sources of revenue, as well as exploit such revenues to establish alternative energy projects, whether from the sun, wind, or both. In addition, the establishment of such projects is suitable for the conditions of the Jordanian environment.
\end{abstract}

Keywords: oil price, government revenues, tax revenues, external grants, government expenditure, government budget

\section{Introduction}

Energy is the most important factor in influencing global production activity. Despite serious attempts to develop the alternative sources of energy, oil remains the most important source and an essential component of numerous economic activities because it provides fuel and energy for the production process of factories. The discovery of oil had been a challenge and an important turning point in the economies of the countries that possess it. These oil countries experienced an economic boom, and all the aspects of life became profoundly prosperous because of the oil revenues that contributed to the growing national income. Oil prices are subject to sharp fluctuations during relatively close periods, which are also a major factor in the global economic and financial instability. Generally, economic and financial stability means to avoid sharp fluctuations in macroeconomic and financial variables. Possibly, the most prominent of these variables that is sensitive to oil prices is that of the state's public budget.

In fact, among the numerous empirical studies conducted since 1973, only that of Hamilton (1983), Mork (1989), and Federer (1996) predominantly focused on the relationship between oil price changes and macroeconomic variables. Few studies have analyzed the impact of oil price fluctuations on certain budget variables, such as that of Eltony and Al-Awadi (2001), which determined a direct impact of oil prices on government spending in Kuwait (one of the oil producers). This finding agreed with the result of many studies conducted on other economies, such as that on the economy of Venezuela (the highest oil-producing country under OPEC by El-Anashasy (2006), which revealed a long-term relationship between oil price volatility and government expenditures. Moreover, the study of Lorde and Thomas (2009) in La Trinidad and Tobago corroborated that increases in oil prices have a positive effect on government revenues and consumption. Moreover, in Tunisia, positive and negative oil price shocks significantly affect government spending (Jbir \& Zouari-Ghorbel, 2009). These results were supported by Almulali and Che Sab (2013), who affirmed that a surge in oil price causes oil revenues to increase in OPEC countries, which, in turn, positively influences government expenditures. However, such matter is yet to be proven.

Several studies have validated that the effect of oil prices on the general budget variables is limited, including that of Christopher and Benedict (2006) and Akin and Babajidie (2011) who based their analysis in Nigeria and 
did not determine any significant effect of oil price changes on government expenditures. Furthermore, Farzanegan and Markwardt (2009) did not discover any significant effect of oil price on government expenditures in Iran.

After evaluating the previous studies, the current study will attempt to analyze the effect of oil price on Jordan's budget variables using simple regression analysis. The budget variables considered in this study are government and tax revenues, external grants, and government expenditures. This study is characterized by previous studies with the following characteristics:

- The current study includes variables (tax revenues and external grants) that have not been addressed in previous studies.

- This study attempts to bridge the gap in the application aspect by determining the impact of the global oil price on Jordan's budget variables. Doing so can enable economic policymakers to determine suitable solutions and reduce the negative effects of oil prices on such variables and, thus, on the budget deficits.

\subsection{Statement of the Problem}

Jordan has an emerging economy that is open to the outside world and is vulnerable to many shocks at the local and external levels. With this, the economy of Jordan suffers from numerous problems.

- Full dependence on oil imports for energy because the oil bill for Jordan is approximately a quarter of its gross domestic product (GDP).

- The grants and aid provided to Jordan by the Gulf oil countries are fluctuating because of the unstable oil revenues of these countries. Undoubtedly, such aid will decline, especially as the decrease in global oil prices has led to a deficit in the budget and to internal actions, including reducing salaries and borrowing from the outside world.

- High tax rates in Jordan, especially indirect taxes, are imposed on basic commodities that affect all the members of society, including taxes on oil derivatives, water, and electricity, which have led to the decreased real incomes of individuals and society.

The above problems are subject to fluctuations in global oil prices and reflect government expenditures and revenues, resulting to an unstable deficit in the government budget of Jordan.

Given the foregoing analysis, the study is guided by the following questions:

1) What is the effect of oil price changes on government revenues in Jordan?

2) What is the effect of oil price changes on tax revenues in Jordan?

3) What is the effect of oil price changes on external grants in Jordan?

4) What is the effect of oil price changes on government expenditures in Jordan?

5) What is the effect of oil price changes on budget deficits in Jordan?

\subsection{Objective of the Study}

Regarding the research questions stated above, the specific objectives of this study are as follows:

1) To econometrically evaluate the impact of oil price changes on the government revenues in Jordan.

2) To econometrically evaluate the impact of oil price changes on tax revenues in Jordan.

3) To econometrically evaluate the impact of oil price changes on external grants in Jordan.

4) To econometrically evaluate the impact of oil price changes on government expenditures in Jordan.

5) To econometrically evaluate the impact of oil price changes on budget deficits in Jordan.

\subsection{Hypotheses of the Study}

The two models and the hypotheses tested in this study are as follows:

1) The changes in oil price have no significant effect on government revenues in Jordan.

2) The changes in oil price have no significant effect on tax revenues in Jordan.

3) The changes in oil price have no significant effect on external grants in Jordan.

4) The changes in oil price have no significant effect on government expenditures in Jordan.

5) The changes in oil price have no significant effect on budget deficits in Jordan. 


\subsection{Significance of the Study}

The study is important for the following reasons:

- The variables of the study are important. Oil is the main source of energy, and the variables of the public budget are among the most prominent indicators of economic and financial stability.

- To enrich the knowledge of those interested in economic and financial affairs and the relationship between oil prices and public budget, particularly in Jordan, where oil imports account for approximately a quarter of its GDP and depend on grants and oil assistance from the Gulf countries.

\subsection{Scope of the Study}

The scope of this study covers the period of 1992 to 2015 (24 years) to ensure that the information and trend are current.

\section{Theoretical Framework}

\subsection{Oil Prices}

Oil and its derivatives are among the most important sources of energy in our modern world, where the oil share is $36.8 \%$ of the total global energy consumption (Khairuddin, 2008, p. 2). Oil is also considered the main operator of the global economic activity. Factories, farms, transportation, and other activities use sources of energy. (Mkhalafi, 2013, p. 1).

Therefore, Any fluctuations of oil prices have significant economic effects on importing and exporting countries. Importing countries are positively affected by the decline in oil prices because they acquire cheap energy; thus, the costs of energy inputs decline. Oil in the exporting countries is considered the main source of the most important macro and micro economic indicators depending on the diversity of the these countries' economies (Ayoub, 2002, p. 9).

Through examining oil prices during the period of this study, a volatile fluctuation has been observed, as shown in Figure 1. The lowest price in this period was recorded during December 1998 as it reached approximately US\$10. In less than a decade, the highest price was recorded during July 2008, exceeding US\$140. Subsequently, the price fell below the US\$30-level at the beginning of 2016 .

The following sharp fluctuations can be distinguished among the prices of crude oil:

A. The prices sharply fell in the late 1990s due to the discovery of new oil production areas, such as the North Sea and Central Asia areas, as well as an unexpected increase in global crude oil inventories (Ayoub, 2002, p. $10)$.

B. The oil prices increased during the period of 2002 to 2008 due to high economic growth rates in China and India, which coincided with a shortage in oil supplies caused by the unrest in Iraq (Al-Khater, 2015, p. 3).

C. The prices sharply fell in 2014 due to the economic recession in the Euro-zone, increase of oil production in the US (Al-Khater, 2015, p. 4).

Fluctuations in oil prices are linked to the demand and supply. In the demand side stands the level of global economic activity and its fluctuation between prosperity and the recession, as well as the climate factors whether the seasons are cool or warm. In the supply side stands the new oil discoveries and energy alternatives, producer policies, crises, and political and security tension in exporting countries (Banikhalid, 2017, p. 168).

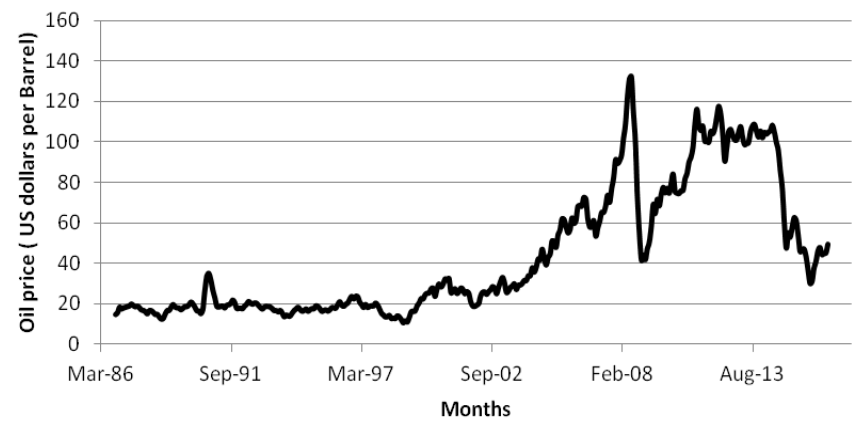

Figure 1. Simple average crude oil prices of Brent on a monthly basis in US dollar during the period of 1992 to 2015

Source: https://www.indexmundi.com/commodities/?commodity=crude-oil\&months=360 


\subsection{Performance Development of Jordan's Government Budget}

Table 1 indicates that Jordan's government budget has observed a deficit that is almost chronic during the past 24 years, except for 1992 to 1996 . Thus, the government budget deficit is chronic. The maximum budget deficit during the study period of 1992 to 2015 was 1,824 million JD in 2012.

Table 1 also shows that, from 1992 to 2015 during the study period, the total government revenues grew from $1,358.7$ million JD to $6,796.4$ at the growth rate of $7.7 \%$; the total tax revenues grew from 639.9 million JD to 4,370 at the growth rate of $9 \%$; and the external grants increased from 137.4 million JD to 886.3 at the growth rate of $23.9 \%$.

By contrast, the total government expenditure grew from 1,291.2 million JD in 1992 to 7,722.9 in 2015 at the growth rate of $8.4 \%$ during the study period.

Table 1. Jordan's budget variables on a yearly basis (in million JD), and Brent's average of oil prices on a yearly basis (US dollars per barrel) during the period of 1992 to 2015

\begin{tabular}{|c|c|c|c|c|c|c|}
\hline Years & $\begin{array}{c}\text { External } \\
\text { grants }\end{array}$ & Tax & $\begin{array}{l}\text { Total revenues of the central } \\
\text { government with assistance }\end{array}$ & $\begin{array}{l}\text { Total expenditures of } \\
\text { the central government }\end{array}$ & $\begin{array}{c}\text { Actual deficit for the } \\
\text { public budget with } \\
\text { assistance }\end{array}$ & $\begin{array}{c}\text { *Average of Brent's } \\
\text { oil prices on a } \\
\text { monthly basis } \\
\end{array}$ \\
\hline 1992 & 137.4 & 639.9 & 1358.7 & 1291.2 & 67.5 & 19.31 \\
\hline 1993 & 163.1 & 643.4 & 1406.1 & 1336.6 & 69.5 & 17.02 \\
\hline 1994 & 175.5 & 694.1 & 1537.3 & 1492.7 & 44.6 & 15.83 \\
\hline 1995 & 182.8 & 758 & 1620 & 1604.8 & 15.2 & 17.07 \\
\hline 1996 & 247.0 & 841.1 & 1723.2 & 1706.6 & 16.6 & 20.65 \\
\hline 1997 & 205.0 & 798.5 & 1620.8 & 1884.2 & -263.4 & 19.09 \\
\hline 1998 & 172.2 & 858.6 & 1701.4 & 2028.7 & -327.3 & 12.72 \\
\hline 1999 & 198.5 & 884.6 & 1815.9 & 1956.3 & -140.4 & 17.81 \\
\hline 2000 & 240.2 & 961.9 & 1850.3 & 1970.1 & -119.8 & 28.27 \\
\hline 2001 & 249.4 & 996.4 & 1967.9 & 2123.5 & -155.6 & 24.42 \\
\hline 2002 & 266.6 & 1000.3 & 2016.6 & 2221.7 & -205.1 & 24.97 \\
\hline 2003 & 687.7 & 1083.2 & 2363.3 & 2442.3 & -79 & 28.35 \\
\hline 2004 & 667.0 & 1428.8 & 2814.2 & 2931 & -116.8 & 38.30 \\
\hline 2005 & 501.0 & 1765.8 & 3063.9 & 3104.3 & -40.4 & 54.44 \\
\hline 2006 & 304.5 & 2133.5 & 3468.9 & 3860.4 & -391.5 & 65.39 \\
\hline 2007 & 343.4 & 2472.1 & 3971.5 & 4540 & -568.5 & 72.70 \\
\hline 2008 & 718.3 & 2758.1 & 5093.7 & 5431.9 & -338.2 & 97.64 \\
\hline 2009 & 333.4 & 2879.9 & 4521.3 & 6030.5 & -1509.2 & 61.86 \\
\hline 2010 & 401.7 & 2989 & 4662.8 & 5708 & -1045.2 & 79.64 \\
\hline 2011 & 1215.0 & 3062.2 & 5413.9 & 6796.6 & -1382.7 & 110.94 \\
\hline 2012 & 327.3 & 3351.4 & 5054.3 & 6878.2 & -1824 & 111.97 \\
\hline 2013 & 639.1 & 3652.5 & 5758.9 & 7077.1 & -1318.2 & 108.86 \\
\hline 2014 & 1236.5 & 4037.1 & 7267.6 & 7851.1 & -583.5 & 98.94 \\
\hline 2015 & 886.3 & 4370 & 6796.4 & 7722.9 & -926.5 & 52.37 \\
\hline \multicolumn{7}{|l|}{ Sources: } \\
\hline $\begin{array}{l}\text { ttp://ws } \\
\text { ttp://ws }\end{array}$ & $\begin{array}{l}\text { hof.gov. } \\
\text { bj.gov.j }\end{array}$ & $\begin{array}{l}\text { Ministry } \\
\text { entral B }\end{array}$ & $\begin{array}{l}\text { Finance). } \\
\text { of Jordan). }\end{array}$ & & & \\
\hline
\end{tabular}

Figure 2 shows the differences between the following periods:

In the period of 1992 to 2006 , the fluctuation was limited to the budget deficit of the government.

In the period of 2007 to 2012, the expansion deficit gap increased.

The period of 2013 to 2015 was characterized by a decrease in the budget deficit of the government. 


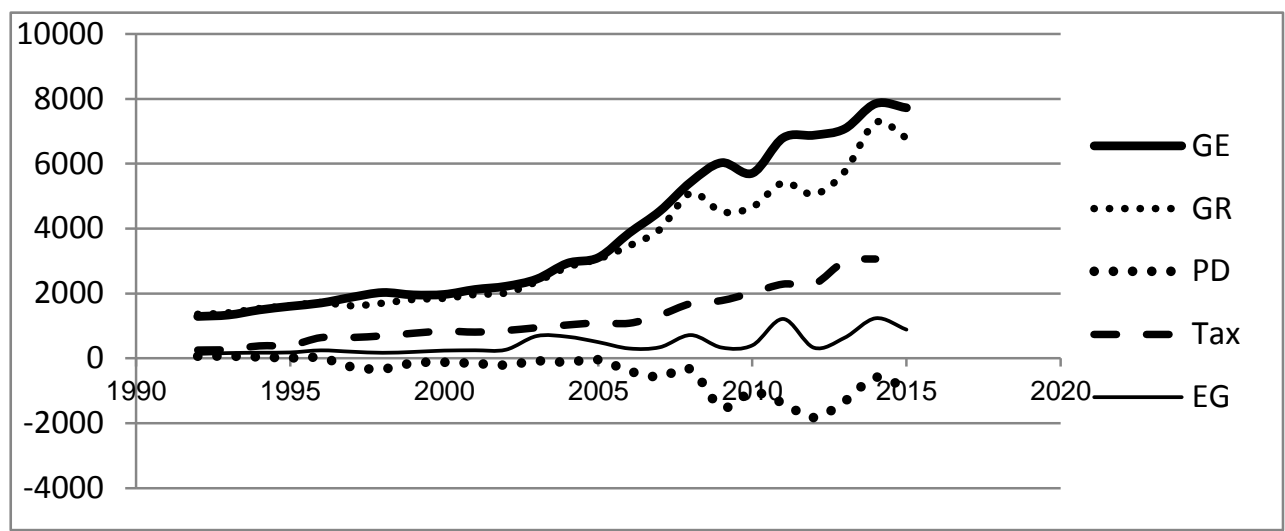

Figure 2. Development of the budget variables, government and tax revenues, external grants, government expenditures, and budget deficits in Jordan, on a yearly basis in JD, during the period of 1992 to 2015

Source: Author's own representation using data from Table 1.

\section{Methodology of the Study}

\subsection{Design of the Study}

this study relied on secondary data that were pooled and accumulated over time. The study used crude oil prices because they account for more than 25\% of the GDP in Jordan. Moreover, data on the variables of the government budget were obtained at the state level to ascertain how the changes in oil prices have affected the revenues and expenditures of the government.

\subsection{Sources of Data}

These data are time series and of regular nature. The researcher relied on the secondary sources of data, such as books, periodicals, theses, and websites.

\subsection{Techniques of Data Collection and Analysis}

In gathering the data, the desk survey method of data collection was employed given the objective and hypothesis of the study. Trend data were obtained for the period of 1992 to 2015. The data consisted of crude oil prices (BP), government revenues (GR), tax revenues (TAX), and external grants (EG) of the country, as well as government expenditures (GE) and government budget deficits (DB) with a view to establishing the impact of oil price changes on the budget variables of the state.

Furthermore, the technique of data analysis adopted in the study was ordinary least squares (OLS) of simple regression. This technique was chosen due to its best linear unbiased estimate feature with in-built validation criteria used in establishing relationships among variables.

\subsection{Model Specification}

The model that was deployed in analyzing the phenomenon followed the models of similar prior studies. Therefore, the model specification is the eclectic approach, expressed as Equation 1:

$$
Y i=f\{X i\}
$$

Where,

Xi: crude oil prices of Brent (BP);

Yi: government revenues (GR), or tax revenues (TAX), or external grants (EG), or government expenditures (GE), or government budget deficits (DB).

An approximately linear correlation was assumed between the dependent variables and the independent variable. Structurally, the above expression is stated as follows:

$$
Y i=\beta 0+\beta 1 X i+\varepsilon i
$$

where

Yi: dependent variables (GR, TAX, EG, GE, DB);

$\beta 0$ : constant;

$\beta 1$ : coefficient; 
$\mathrm{Xi}$ : independent variable (BP);

عi: random error term.

\section{Regression Analysis}

4.1 Estimating and Assessing the Impact of BP on the Government Revenues in Jordan

Estimating the regression model:

Table 2. Regression result for BP on GR

\begin{tabular}{cccc}
\hline Variable & Coefficient & t- Statistic & Prob \\
\hline BP & 46.13 & 8.52 & 0.000 \\
C & 982.00 & & 2.99 \\
Adjusted $\mathrm{R}^{2}: \% 75$ & $\mathrm{~F}=72.74$ \\
$\mathrm{R}^{2}: \% 76$ & $\mathrm{n}=24$ & 0.006 \\
\hline
\end{tabular}

Source: Author's own representation using E-view program.

Estimating the equation for the first model:

$$
G R=982.00+46.13 B P
$$

Assessing the regression model:

1). Assessing the model according to economic criteria. The second column of Table (2) (Coefficient) shows that the coefficient of BP is 46.13 at the long run during the period of 1992 to 2015. Hence, the oil price in the long run is one of the main factors to influence the decision of the government in determining its GR level. Therefore, changing the budget policy to reduce or remove budget deficits is necessary.

2). Assessing the model according to the statistical standard. The model indicates that the coefficient of determination is (adjusted $\mathrm{R}^{2}: 75 \%$ ), which means that changes in the independent variable explain approximately $75 \%$ of the changes in the dependent variable. Although the value of F-statistic has reached 72.74 and the P-value for this hypothesis is 0.000 or less than $5 \%$, the null hypothesis can be rejected, and the alternative hypothesis can be accepted. Therefore, a significant impact exists between oil price (BP) and government revenues in Jordan.

3) Testing the forecasting ability of the first model

The viability of the model and its forecasting ability for government revenues in Jordan can be tested by using the dispersion factor standard (variance proportion), as shown below:

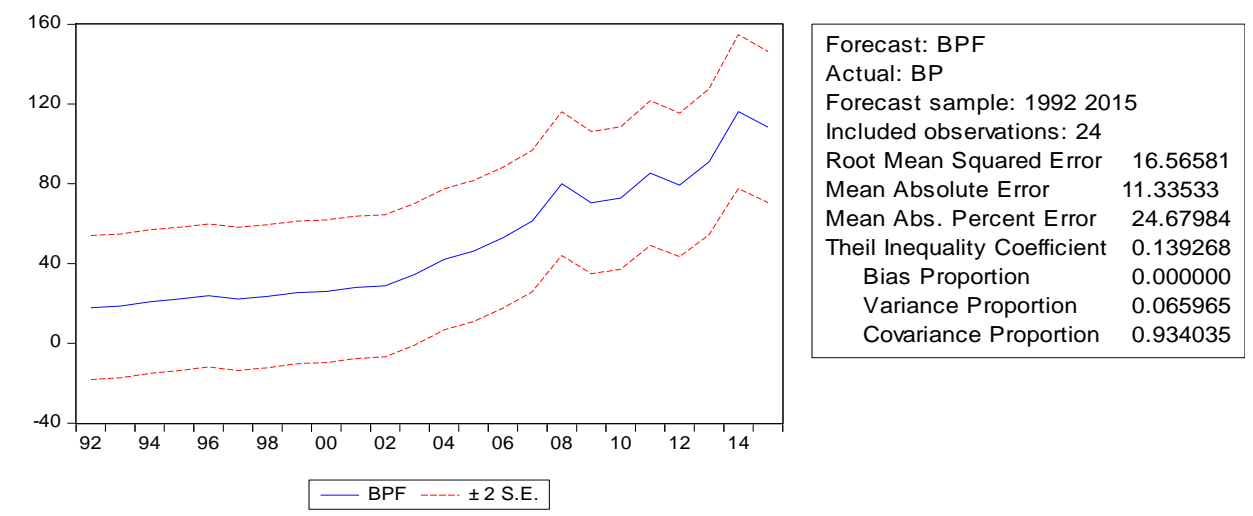

Figure 3. Testing the forecasting ability of the model

Source: Author's own representation using E-view program.

The model has an acceptable forecasting ability through variance proportion, where it was estimated at 0.06 , suggesting that the model's forecasting ability of government revenues in Jordan is acceptable.

\subsection{Estimating and Assessing the Impact of BP on the Tax Revenues in Jordan}

Estimating the regression model: 
Table 3. Regression result for BP on TAX

\begin{tabular}{|c|c|c|c|}
\hline Variable & Coefficient & $\mathrm{t}$ - Statistic & Prob \\
\hline BP & 30.31 & 8.37 & 0.000 \\
\hline $\mathrm{C}$ & 363.48 & 1.65 & 0.111 \\
\hline Adjusted $\mathrm{R}^{2}: \% 75$ & & $\mathrm{~F}=70.2$ & \\
\hline $\mathrm{R}^{2}: \% 76$ & & $\mathrm{n}=24$ & \\
\hline
\end{tabular}

Source: Author's own representation using E-view program.

Estimating the equation for the second model :

$$
T A X=363.48+30.31 B P
$$

Assessing the regression model:

1). Assessing the model according to economic criteria: The second column of Table 3 (Coefficient), shows that the coefficient of BP is (BP) is 30.31 at the long run during the period of 1992 to 2015 . Hence, the oil price in the long run is one of the main factors to influence a decision of the government in determining its TAX level. Therefore, changing the budget policy to reduce or remove budget deficits is necessary.

2). Assessing the model according to the statistical standard. The model indicates that the coefficient of determination is (adjusted $\mathrm{R}^{2}: 75 \%$ ), which means that changes in the independent variable explain approximately $75 \%$ of the changes in the dependent variable. Although the value of F-statistic has reached 70.2 and the P-value for this hypothesis is 0.000 or less than 5\%, the null hypothesis can be rejected, and the alternative hypothesis can be accepted. Therefore, a significant impact exists between oil price (BP) and tax revenues in Jordan.

3) Testing the forecasting ability of the second model: The viability of the model and its forecasting ability for tax revenues in Jordan can be tested by using the dispersion factor standard (variance proportion), as shown below:

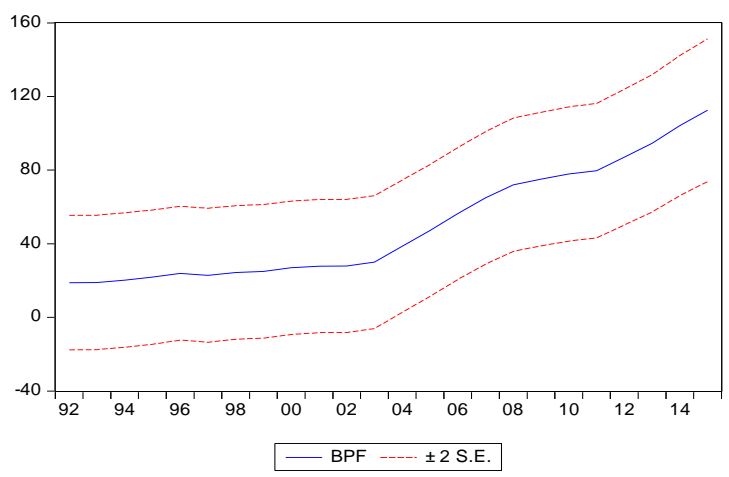

$$
\begin{aligned}
& \text { Forecast: BPF } \\
& \text { Actual: BP }
\end{aligned}
$$

Figure 4. Testing the forecasting ability of the model

Source: Author's own representation using E-view program.

The model has an acceptable forecasting ability through variance proportion, where it was estimated at 0.07 , suggesting that the model's forecasting ability of tax revenues in Jordan is acceptable.

\subsection{Estimating and Assessing the Impact of BP on the External Grants in Jordan}

Estimating the regression model:

Table 4. Regression result for BP on EG

\begin{tabular}{cccc}
\hline Variable & Coefficient & t- Statistic & Prob \\
\hline $\mathrm{BP}$ & 6.02 & 4.14 & 0.000 \\
$\mathrm{C}$ & 136.36 & 1.54 & 0.136 \\
\hline Adjusted $\mathrm{R}^{2}: \% 41$ & $\mathrm{~F}=17.14$ \\
$\mathrm{R}^{2}: \% 43$ & $\mathrm{n}=24$ & \\
\hline
\end{tabular}

Source: Author's own representation using E-view program. 
Estimating the equation for the third model:

$$
\mathrm{EG}=136.36+6.02 \mathrm{BP}
$$

Assessing the regression model

1). Assessing the model according to economic criteria: The second column of Table 4 (Coefficient shows that the coefficient of $\mathrm{BP}$ is 6.02 at the long run during the period of 1992 to 2015. Hence, the oil price in the long run is one of the main factors to influence the decision of the government in determining its EG level. Therefore, changing the budget policy to reduce or remove budget deficits is necessary.

2). Assessing the model according to the statistical standard. The model indicates that the coefficient of determination is (adjusted $\mathrm{R}^{2}: 41 \%$ ), which means that changes in the independent variable explain approximately $41 \%$ of the changes in the dependent variable. Although the value of F-statistic has reached 17.14 and the P-value for this hypothesis is 0.000 or less than 5\%, the null hypothesis can be rejected, and the alternative hypothesis can be accepted. Therefore, a significant impact exists between oil price (BP) and external grants in Jordan.

3). Testing the forecasting ability of the third model: The viability of the model and its forecasting ability for external grants in Jordan can be tested by using the dispersion factor standard (variance proportion), as shown below:

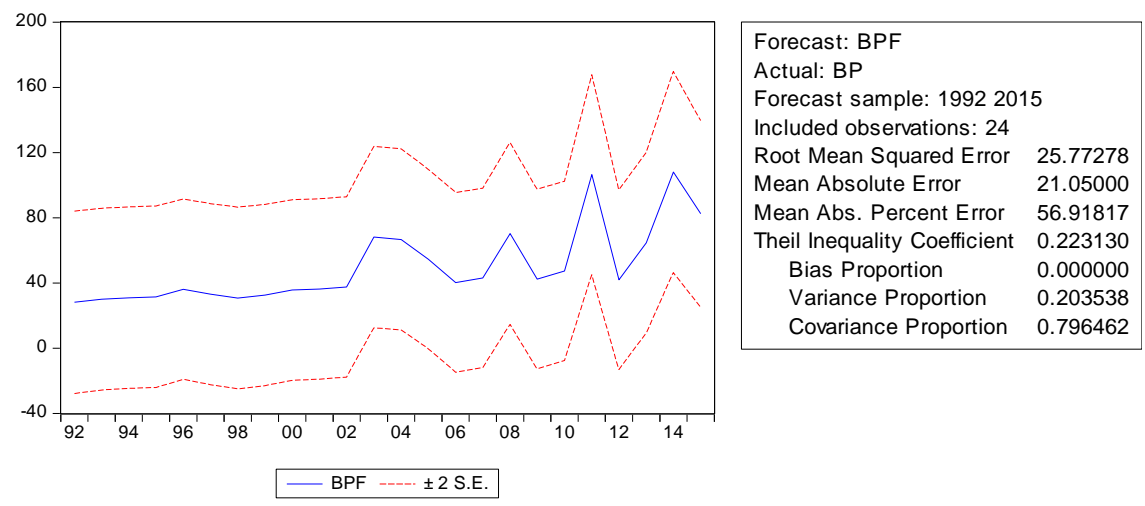

Figure 5. Testing the forecasting ability of the model

Source: Author's own representation using E-view program.

The model has an acceptable forecasting ability through variance proportion, where it was estimated at 0.20 , suggesting that the model's forecasting ability of external grants in Jordan is acceptable.

4.4 Estimating and Assessing the Impact of BP on the Government Expenditure in Jordan

Estimating the regression model:

Table 5. Regression result for BP on GE

\begin{tabular}{cccc}
\hline Variable & Coefficient & t- Statistic & Prob \\
\hline BP & 58.74 & 9.53 & 0.000 \\
$\mathrm{C}$ & 815.73 & 2.18 & 0.04 \\
\hline Adjusted $\mathrm{R}^{2}: \% 79$ & $\mathrm{~F}=90.86$ & \\
$\mathrm{R}^{2}: \% 80$ & & $\mathrm{n}=24$ & \\
\hline
\end{tabular}

Source: Author's own representation using E-view program.

Estimating the equation for the fourth model:

$$
G E=815.73+58.74 B P
$$

Assessing the regression model

1). Assessing the model according to economic criteria. The second column of Table 5 (Coefficient) shows that the coefficient of BP is 58.74 at the long run during the period of 1992 to 2015 . Hence, the oil price in the long 
run is one of the main factors to influence the decision of the government in determining its GE level. Therefore, changing the budget policy to reduce or remove budget deficits is necessary.

2). Assessing the model according to the statistical standard. The model indicates that the coefficient of determination is (adjusted $\mathrm{R}^{2}: 79 \%$ ), which means that changes in the independent variable explain approximately $79 \%$ of the changes in the dependent variable. Although the value of F-statistic has reached 90.86 and the P-value for this hypothesis is 0.000 or less than $5 \%$, the null hypothesis can be rejected, and the alternative hypothesis can be accepted. Therefore, a significant impact exists between oil price (BP) and government expenditure in in Jordan.

3). Testing the forecasting ability of the fourth model: The viability of the model and its forecasting ability for government expenditure in Jordan can be tested by using the dispersion factor standard (variance proportion), as shown below:

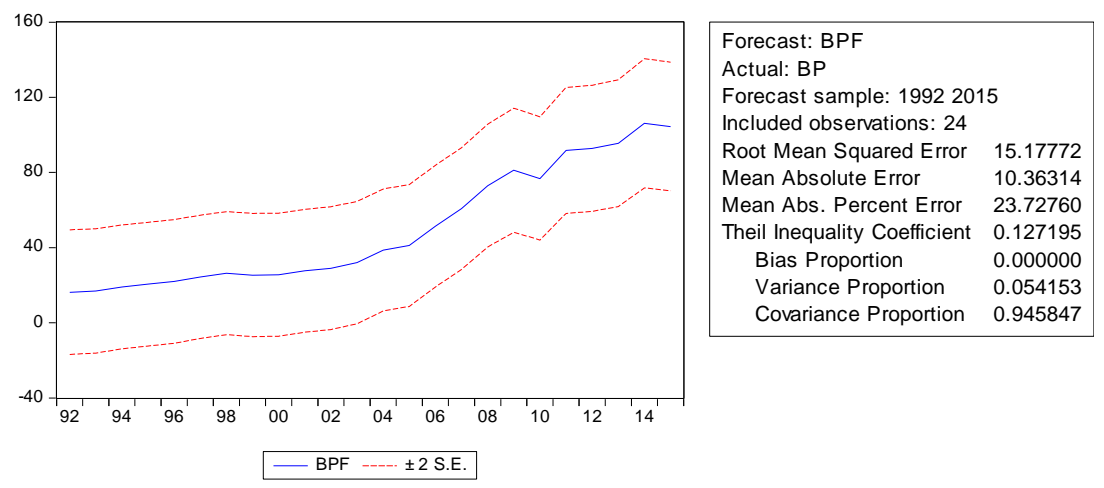

Figure 6. Testing the forecasting ability of the model

Source: Author's own representation using E-view program.

The model has an acceptable forecasting ability through variance proportion, where it was estimated at 0.05 , suggesting that the model's forecasting ability of government expenditure in Jordan is acceptable.

\subsection{Estimating and Assessing the Impact of BP on Budget Deficit in Jordan}

Estimating the regression model:

Table 6. Regression result for BP on BD

\begin{tabular}{|c|c|c|c|}
\hline Variable & Coefficient & t- Statistic & Prob \\
\hline BP & -12.60 & -5.97 & 0.000 \\
\hline $\mathrm{C}$ & 166.27 & 1.29 & 0.207 \\
\hline Adjusted $\mathrm{R}^{2}: \% 60$ & & & \\
\hline $\mathrm{R}^{2}: \% 61$ & & & \\
\hline
\end{tabular}

Source: Author's own representation using E-view program.

Estimating the equation for the fifth model:

$$
B D=166.27-12.60 \mathrm{BP}
$$

Assessing the regression model

1). Assessing the model according to economic criteria. The second column of Table 6 (Coefficient) shows that the coefficient of BP is -12.60 at the long run during the period of 1992 to 2015 . Hence, the oil price in the long run is one of the main factors to influence the decision of the government in determining its BD level. Therefore, changing the budget policy to reduce or remove budget deficits is necessary.

2). Assessing the model according to the statistical standard. The model indicates that the coefficient of determination is (adjusted $\mathrm{R}^{2}: 60 \%$ ), which means that changes in the independent variable explain approximately $60 \%$ of the changes in the dependent variable. Although the value of F-statistic has reached 35.64 and the P-value for this hypothesis is 0.000 or less than $5 \%$, the null hypothesis can be rejected, and the alternative hypothesis can be accepted. Therefore, a significant impact exists between oil price (BP) and budget deficit in Jordan. 
3). Testing the forecasting ability of the fifth model: The viability of the model and its forecasting ability for budget deficit in Jordan can be tested by using the dispersion factor standard (variance proportion), as shown below:
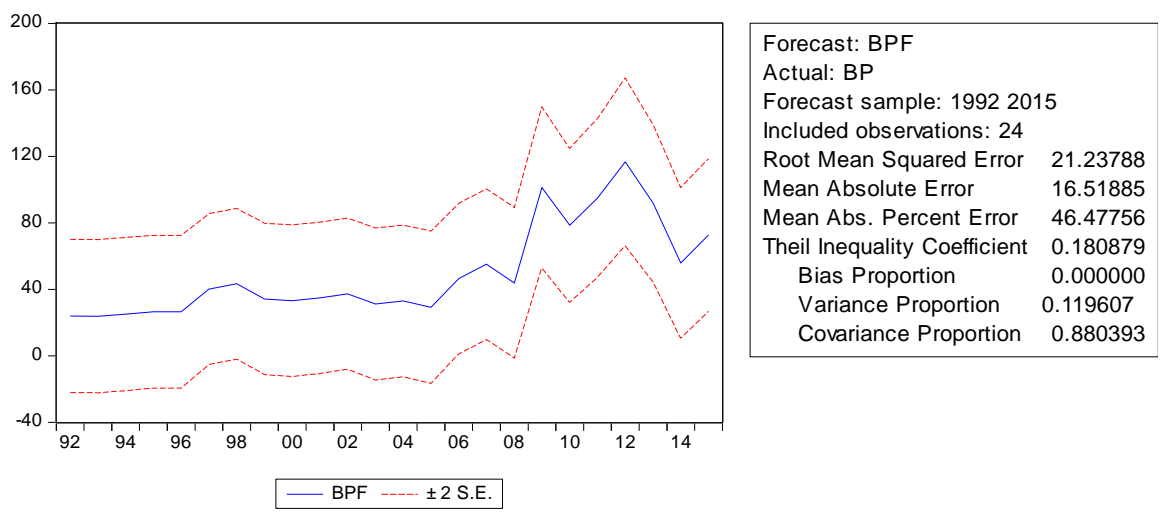

Figure 7. Testing the forecasting ability of the model

Source: Author's own representation using E-view program.

The model has an acceptable forecasting ability through variance proportion, where it was estimated at 0.12 , suggesting that the model's forecasting ability of budget deficit in Jordan is acceptable.

\section{Conclusion and Policy Implication}

\subsection{Conclusion}

This study examined the effect of oil price changes on certain budget variables in Jordan. Specifically, the study assessed if crude oil price changes affected government and tax revenues, external grants, government expenditures, as well as budget deficits of the country over the period of 1992 to 2015. Econometric techniques that included OLS were used to determine the direction of causality and the magnitude of impacts. Findings from the analysis affirmed a statistically significant positive correlation for crude oil price on government and tax revenues, external grants, and government expenditures. Although a statistically significant negative correlation for crude oil price on budget deficits was observed, the increase in crude oil price also leads to an increase in the budget deficits of Jordan.

Considering the above findings, we conclude that the decrease in crude oil prices will expose government revenues to decline, which will increase the government budget deficit. In addition, increasing crude oil prices will lead to an increase of government expenditures, which will increase the budget deficits of Jordan.

\subsection{Policy Implication}

On the basis of the above findings, the following recommendations are proposed:

- The government of Jordan should exercise caution in tax policy on oil derivatives during the periods of high oil prices. The reason is that the increase in tax rates during these periods can negatively affect the GDP through its effect on income, consumption, savings, and investment, especially that the market in Jordan is currently facing a state of economic downturn.

- The government of Jordan should invest oil tax revenues in economic sectors, such as agriculture and manufacturing, to broaden the sources of revenue, as well as exploit such revenues in establishing alternative energy projects, whether from the sun, wind, or both. The establishment of such projects is suitable for the conditions of the environment in Jordan.

- The external grants submitted to Jordan are frequently based on political positions and not only on oil prices. Therefore, such grants can disappear. Thus, Jordan should gradually reduce its dependence on external grants.

- Jordan must take the necessary legal measures to recover the misappropriated public funds and end the reckless spending of revenues.

- Further studies should be conducted to test the effect of crude oil price on economic and financial variables in Jordan, such as consumption, savings, total and foreign investments, and investment indicators in the Amman Stock Exchange. 


\section{References}

Akin, I., \& Babajidie, F. (2011). Impact of oil price shocks on selected macroeconomic variables in Nigeria. Energy Policy, 39, 603-612. https://doi.org/10.1016/j.enpol.2010.10.033

Al-Khater, K. (2015). The Challenges of Oil Price Crises and Economic Diversification in the GCC States. Arab Center for Research and Policy Studies, Doha. Retrieved from https://www.dohainstitute.org/ar/Lists/ACRPS-PDFDocumentLibrary/Khaled_AlKhater_Paper_on_Gas_an d_Oil_Prices_Collapse_Challenges_in_GCC.pdf

Almulali, U., \& Che Sab, C. N. (2013). Exploring the impact of oil revenues on OPEC members macro economy. Energy Review, 37(4), 416-428. https://onlinelibrary.wiley.com/doi/abs/10.1111/opec.12014

Ayoub, M. (2002). Towards an Arab oil policy. the Zayed Center for Coordination and Follow-up, United Arab Emirates.

Banikhalid, H. (2017). The Impact of Oil Prices on the G7's Inflation Rate. International Journal of Economics and Finance, 9, 674-690. https://doi.org/10.5539/ijef.v9n6p167

Christopher, A., \& Benedict, G. (2006). Monetary policy and oil price surges in Nigeria. Paper presented at centre for the study of African Economies, Oxford University.

El-Anashasy, A. (2006). Oil prices, fiscal policy, and Venezuela's economic growth. Working Paper, University of Washington.

Eltony, M. N., \& Al-Awadi, M. (2001). Oil price fluctuations and their impact on the macroeconomic variables of Kuwait: a case study using a VAR model. International Journal of Energy Research, 25(11), 939-959. https://doi.org/10.1002/er.731

Farzanegan, M., \& Markwardt, G. (2009). The effects of oil price shocks on the Iranian economy. Energy Economics, 31(1), 134-151. https://doi.org/10.1016/j.eneco.2008.09.003

Federer, J. P. (1996). Oil Prices Volatility and the macro economy. Journal of Macro Economy, 18, 1-26. https://doi.org/10.1016/S0164-0704(96)80001-2

Hamilton, J. (1983). Oil and macroeconomic since world war II. Journal of Political Economy, 91(2), 228-248. https://doi.org/10.1086/261140

Jbir, R., \& Zouari-Ghorbel, S. (2009). Recent oil price shock and the Tunisian economy. Energy Policy, 37(3), 1041-1051. https://doi.org/10.1016/j.enpol.2008.10.044

Khairuddin, M. (2008). The Influence of Oil Price Fluctuations on Inflation and Trade Balance in Jordan. Unpublished Master Thesis, University of Jordan.

Lorde, T. J., \& Thomas, C. (2009). The macroeconomic effects of oil price fluctuations on samll openoil-producing country: The case of Trinidad and Tobago. Energy Policy, 37(7), 2708-2716. https://doi.org/10.1016/j.enpol.2009.03.004

Mkhalafi A. (2013). Introduction to Petroleum Economics. University of Kasdi Merbah - Ouargla. Retrieved from http://www.uomisan.edu.iq/library/admin/book/81387072894.pdf

Mork, K. (1989). Oil price and macroeconomy when oil price go up and down: An exploration to Hamilton's results. Journal of Political Economy, 97(3), 740-744. https://doi.org/10.1086/261625

\section{Copyrights}

Copyright for this article is retained by the author(s), with first publication rights granted to the journal.

This is an open-access article distributed under the terms and conditions of the Creative Commons Attribution license (http://creativecommons.org/licenses/by/4.0/). 